\title{
The effect of dietary essential fatty acids on the concentration of serum and liver lipids in the rat
}

\author{
By A. J. SINCLAIR* AND F. D. COLLINS \\ Russell Grimwade School of Biochemistry, \\ University of Melbourne, Australia
}

(Received 30 December 1969-Accepted 4 Fune 1970)

\begin{abstract}
I. By feeding safflower-seed oil to rats deficient in the essential fatty acids it was found that major changes in the liver and serum triglycerides had occurred in $4 \mathrm{~d}$ although the fatty acid composition had not fully returned to normal.

2. Rats which had been on a saturated-fat diet for 18 weeks were given for $4 \mathrm{~d}$, a diet supplemented with safflower-seed oil, methyl linolenate or ethyl arachidonate. Linoleic and linolenic acids failed to reduce the liver triglycerides but had some effect in raising the serum triglycerides to normal. Arachidonic acid reduced liver triglycerides but had no effect on serum lipids. There were marked changes in the fatty acid composition of the phospholipids but little change in the triglycerides.

3. There was good correlation between the concentrations of the phospholipids and the triglycerides in the serum. The concentration of serum phospholipids was positively correlated with the percentage of linoleic and arachidonic acids but negatively correlated with the percentage of palmitoleic, oleic and 5,8, I I-eicosatrienoic acids.

4. In a further $4 \mathrm{~d}$ feeding experiment in which the lipoprotein fraction of very low density from the serum was measured, it was found that safflower-seed oil led to an increase but methyl arachidonate resulted in a decrease in the concentration of the lipids.

5. Extraction of the lipoprotein fraction of very low density from normal and deficient rats with $\mathrm{n}$-heptane at $-18^{\circ}$ indicated that phosphatidyl cholines containing stearic acid and either arachidonic or $5,8, \mathrm{I}$ I-eicosatrienoic acid were the most firmly bound.

6. It was concluded that linoleic acid and arachidonic acid had different and specific roles in lipid metabolism.
\end{abstract}

A dietary requirement for the essential fatty acids has been well established (AlfinSlater \& Aftergood, I968; Holman, 1968) and the changes in fatty acid composition and deficiency symptoms as between normal and deficient animals have been fully described. The change from the normal to the deficient state is slow, taking up to Io weeks (Sinclair \& Collins, I968), but the reverse change is rapid, and it is easier to study the biochemical processes taking place. In the present study deficient rats were given linoleic, linolenic and arachidonic acids for a short period in order to investigate the relative effects on liver and serum lipids and to measure their relative effectiveness in curing the deficiency symptoms.

\section{METHODS}

Animals and diets

The male Buffalo rats used in these experiments were an inbred strain of SpragueDawley rats obtained from Holtzmann's Rat Farm, Madison, Wisconsin. Rats between 19 and $24 \mathrm{~d}$ of age were placed on the experimental diets and were allowed continuous

* Present address: Health Sciences Centre, Department of Biochemistry, University of Western Ontario, London, 72, Ontario, Canada. 
access to food and water. Normally they were maintained for at least 12 weeks on two different diets. One contained adequate linoleic acid $(4 \%$ of calories as linoleate, control diet) and the other only saturated fat (deficient diet) (Sinclair \& Collins, I968). The percentage composition of the diets was as follows: fat 5 , sucrose 64 , fat-free casein (Nutritional Biochemicals Corp.) 25, cellulose 2, salt mixture (Nutritional Biochemicals Corp.; US Pharmacopeia, XIV, 1950) 4, and vitamin mixture equivalent to $0.5 \%$ of the diet (vitamin diet fortification mixture in dextrose; Nutritional Biochemicals Corp.). After ro weeks on the saturated-fat diet the rats showed signs of a deficiency of essential fatty acids (Sinclair \& Collins, r968).

Table I. Design of the different dietary experiments with rats

\begin{tabular}{|c|c|c|c|c|}
\hline Expt & Diet & Time on diet & $\begin{array}{l}\text { No. of } \\
\text { animals }\end{array}$ & Table or figure \\
\hline I & $\begin{array}{l}\text { (a) } \mathrm{SF} \\
\text { (b) } \mathrm{SF}+\text { safflower seed } \\
\text { oil }(18: 2) \\
\text { (c) } \mathrm{SF}+18: 2 \\
\text { (d) } \mathrm{SF}+18: 2 \\
\text { (e) Control }\end{array}$ & $\begin{array}{l}12 \text { weeks } \\
+4 \mathrm{~d} \\
+7 \mathrm{~d} \\
+12 \mathrm{~d} \\
12 \text { weeks }\end{array}$ & $\left.\begin{array}{l}2 \\
2 \\
2 \\
2 \\
2\end{array}\right\}$ & Figs. 1 and 2 \\
\hline 2 & $\begin{array}{l}\text { (a) } \mathrm{SF} \\
\text { (b) } \mathrm{SF}+18: 2 \\
\text { (c) } \mathrm{SF}+\mathrm{I} 8: 3 \\
\text { (d) } \mathrm{SF}+20: 4 \text { (ethyl) } \\
\text { (e) Control }\end{array}$ & $\begin{array}{l}\text { I } 8 \text { weeks } \\
+4 \mathrm{~d} \\
+4 \mathrm{~d} \\
+4 \mathrm{~d} \\
\text { I } 8 \text { weeks }\end{array}$ & $\left.\begin{array}{l}4 \\
4 \\
4 \\
4 \\
4\end{array}\right\}$ & Tables 2-6 \\
\hline 3 & $\begin{array}{l}\text { (a) } \mathrm{SF} \\
\text { (b) } \mathrm{SF}+\mathrm{I} 8: 2 \\
\text { (c) Control } \\
\text { (d) Control + SF } \\
\text { (e) Control + SF } \\
\text { (f) Control + SF }\end{array}$ & $\begin{array}{l}\text { I } 8 \text { weeks } \\
+4 \mathrm{~d} \\
\text { I } 6 \text { weeks } \\
+2 \text { weeks } \\
+3 \text { weeks } \\
+5 \text { weeks }\end{array}$ & $\left.\begin{array}{l}8 \\
4 \\
8 \\
3 \\
3 \\
3\end{array}\right\}$ & Table 7 and Fig. 3 \\
\hline 4 & $\begin{array}{l}\text { (a) } \mathrm{SF} \\
\text { (b) } \mathrm{SF}+\mathrm{I} 8: 2 \\
\text { (c) } \mathrm{SF}+20: 4 \text { (methyl) } \\
\text { (d) Control }\end{array}$ & $\begin{array}{l}\text { I } 8 \text { weeks } \\
+4 \mathrm{~d} \\
+4 \mathrm{~d} \\
\text { 1 } 8 \text { weeks }\end{array}$ & $\left.\begin{array}{l}3 \\
3 \\
3 \\
3\end{array}\right\}$ & Tables 8 and 9 \\
\hline
\end{tabular}

In further experiments, groups of deficient rats were given $200 \mathrm{mg} / \mathrm{d}$ (Rahm \& Holman, I964) of three different polyenoic acids. Rats which had been on the saturatedfat diet for at least 12 weeks were given a diet which contained only $3.3 \%$ saturated fat plus one of the following supplements administered orally each day for up to I2 d: (a) $260 \mathrm{mg}$ safflower-seed oil (77\% linoleic acid, Sinclair \& Collins, I968); $(b)$ $200 \mathrm{mg}$ methyl linolenate ( $>99 \%$ pure), prepared in this laboratory from linseed oil by the method of White \& Quackenbush (1962); $(c) 257 \mathrm{mg}$ ethyl arachidonate ( $78 \%$ pure), a gift from Hoffman-La Roche, Basle, Switzerland; $(d)$ 2I 3 mg methyl arachidonate ( $94 \%$ pure), from the Hormel Institute. The composition of the above lipids was confirmed by gas chromatography, which showed that any contamination was due to compounds with retention values equivalent to either saturated or monoenoic methyl esters. The rats were given these lipids by mouth in order to control the amount received per $\mathrm{d}$ and also to prevent oxidation. As a further precaution against oxidation, 
$\alpha$-tocopherol (Koch Light Laboratories) was added to each of the above lipids ( $3 \mathrm{mg} / \mathrm{g}$ lipid). Table I describes the use of the above diets in the different experiments. The rats were fasted for $6 \mathrm{~h}$ before death (Sinclair \& Collins, I 968 ) in all experiments.

\section{Analytical methods}

Serum from the rats was either stored at $-18^{\circ}$ or used immediately for preparation of lipoproteins of very low density (VLD). The density of this fraction was less than I.006 and it was prepared as described by Havel, Eder \& Bragdon (1955). Lipids were extracted from the liver, serum and VLD lipoproteins, and the triglycerides, free fatty acids and phospholipids were separated by thin-layer chromatography (Sinclair \& Collins, 1968). The triglycerides and phospholipids were determined as described by Sinclair \& Collins (1968). Concentrations of free fatty acids in the serum were determined by gas chromatography using methyl arachidate as an internal standard. Lipid phosphorus was determined in the lipoprotein lipids using the method of Itaya \& Ui (1966).

\section{Gas-liquid chromatography}

The methyl esters of the fatty acids from triglycerides and phospholipids were prepared by reacting the lipids with $5 \% \mathrm{H}_{2} \mathrm{SO}_{4}$ in methanol at $70^{\circ}$ for $3 \mathrm{~h}$ under nitrogen. This mixture was then diluted with water and the esters were extracted into light petroleum (b.p. $40-60^{\circ}$ ) and stored ready for gas chromatography.

Methyl esters were separated using an F \& M Research Chromatograph 810 (Hewlett Packard). The chromatograph was fitted with an $180 \mathrm{~cm}$ glass column packed with 10\% EGSS-X on 100/120 mesh Gaschrom P (Applied Science Laboratories). A flame ionization detector was used and the equipment was standardized with National Institutes of Health, USA, standards A, B, C and D (Horning, Ahrens, Lipsky, Mattson, Mead, Turner \& Goldwater, 1964). The following methyl esters were identified by their relative retention times: $20: 3 \omega 9,20: 3 \omega 6,20: 5^{\omega}{ }_{3}$ and 22: $5 \omega 6$ (Hofstetter, Sen $\&$ Holman, 1965). All other methyl esters were identified by comparison with authentic samples.

\section{Extraction of lipids from VLD lipoproteins with $n$-heptane}

The VLD lipoproteins were isolated from four control rats and the resulting solution was then dialysed for $48 \mathrm{~h}$ at $4^{\circ}$ against four changes of disodium ethylenediaminetetraacetate, $\mathrm{pH} 77^{\circ} \circ\left(0^{\circ} \circ \mathrm{I} \mathrm{g} / \mathrm{I} / 00 \mathrm{ml}\right.$ ) (Gustafson, 1965$)$. Insoluble potato-starch powder ( $40 \mathrm{mg} / \mathrm{mg}$ protein) was added to the lipoprotein solution (Camejo, 1967) and this mixture was then frozen in liquid nitrogen and freeze-dried. The sample was then extracted four times with $n$-heptane at $-18^{\circ}$ (Gustafson, 1965) and the remaining lipids were extracted with chloroform-ethanol $(2: \mathrm{I}, \mathrm{v} / \mathrm{v})$ at room temperature. The two lipid extracts were then separated into neutral lipids and phospholipids (Galanos \& Kapoulas, 1962); thin-layer chromatography showed that phosphatidyl choline was the only phospholipid present. The methyl esters of the phospholipid fatty acids were prepared and analysed by gas chromatography as described above. This experiment was performed twice with control rats and once with deficient rats ( 14 weeks on diet). 


\section{Statistical analyses}

Standard errors, regression equations and tests of significance were performed as described by Snedecor (1946). The correlation coefficients shown in Table 7 were obtained using the computer programme of Efromyson (1960).

\section{RESULTS}

Deficient rats given polyenoic fatty acids for up to $12 d$

Fig. I shows that after $4 \mathrm{~d}$ of feeding safflower-seed oil to deficient rats, the triglyceride concentrations in the liver and the serum had returned towards normal and that subsequent changes were small. Fig. 2 shows that in the liver phospholipid fatty acids the largest change had taken place in the first $4 \mathrm{~d}$. There was no alleviation of the dermal symptoms in these rats over the $12 \mathrm{~d}$ period. It was decided that more detailed measurements be carried out on deficient rats which had been fed with polyenoic fatty acids for only $4 \mathrm{~d}$ (Expt 2, Table I).

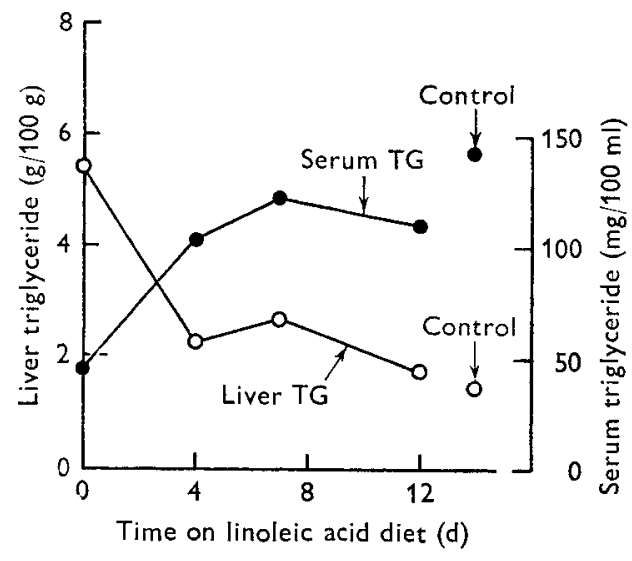

Fig. I

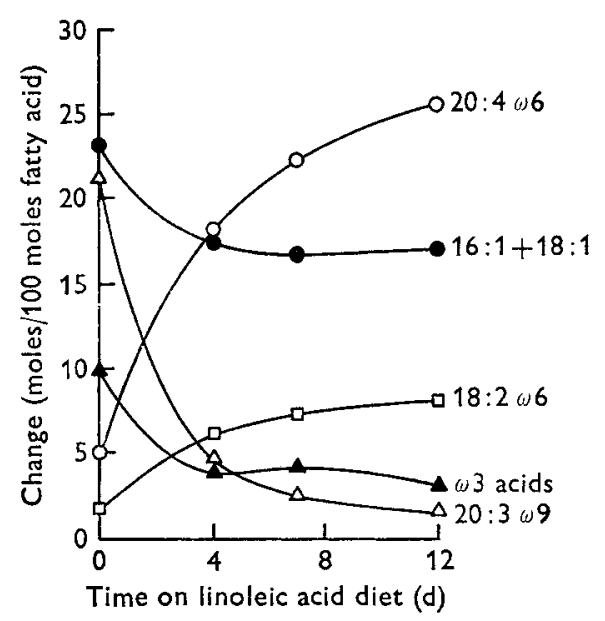

Fig. 2

Fig. I. Expt I. Comparisons of liver and serum triglycerides from deficient rats given linoleic acid for $I 2 \mathrm{~d}$. The results are the mean for two rats at each time-point.

Fig. 2. Expt r. Changes in liver phospholipid fatty acids from deficient rats given linoleic acid for $12 \mathrm{~d}$. The results are the mean for two rats at each time-point.

Table 2 shows that the three polyenoic acids (linoleic, linolenic and arachidonic acids) were equally effective in increasing both the growth rate and the efficiency of utilization of the food. Another characteristic of the deficient state was the fatty liver, but here not all three polyenoic acids were equally effective in restoring the triglyceride concentration to normal and only arachidonic acid produced a significant effect (Table 3).

Rats on diets deficient in the essential fatty acids had low serum triglyceride concentrations (Lyman, Ostwald, Bouchard \& Shannon, I966; Sinclair \& Collins, I968); this result has also been observed in pigs (Leat, 1963 ). Table 3 shows that linoleic and 
linolenic acids markedly increased these concentrations but arachidonic acid failed to do so.

The fatty acid compositions of the triglycerides in the liver and the serum are shown in Table 4 and of the phospholipids in Table 5. In the phospholipids there was a decrease in 5,8, I I-eicosatrienoic, oleic and palmitoleic acids and a corresponding rise in either linoleic, arachidonic or the polyenoic acids from the $\omega_{3}$ series, depending on which polyenoic acid was given. In the triglycerides, however, refeeding for $4 \mathrm{~d}$ had little effect on the fatty acid composition.

Table 2. Expt 2. Comparisons of live weight and food intake of deficient rats which had been given polyenoic fatty acids for $4 d$

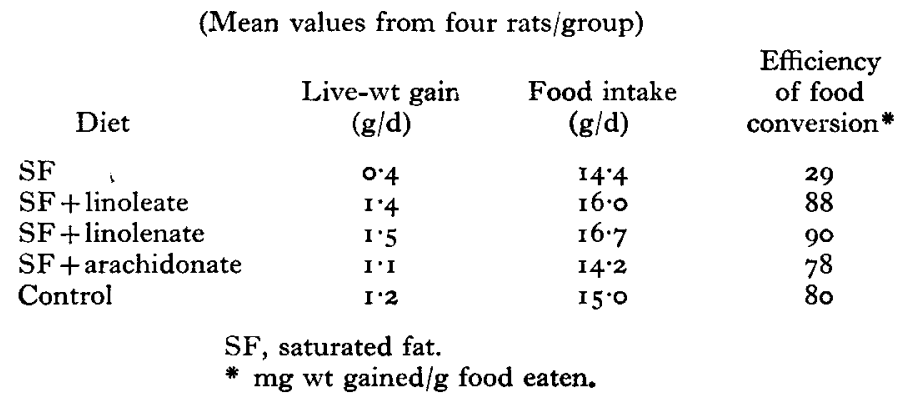

Table 3. Expt 2. Liver and serum triglycerides and phospholipids from deficient rats given polyenoic fatty acids for $4 d$

(Mean values with their standard errors from four rats/group)

SF, saturated fat.

\begin{tabular}{|c|c|c|}
\hline Diet & Triglyceride & Phospholipid \\
\hline \multicolumn{3}{|c|}{ Liver (g lipid/100 g liver) } \\
\hline SF & $3.7 \pm 0.6$ & $2.9 \pm 0.1$ \\
\hline SF + linoleate & $3.8 \pm 0.9$ & $2 \cdot 6 \pm 0.1$ \\
\hline $\mathrm{SF}+$ linolenate & $3.4 \pm 0.9$ & $2.6 \pm 0.2$ \\
\hline $\mathrm{SF}+$ arachidonate & $2 \cdot 1 \pm 0 \cdot 2^{*}$ & $3 \cdot 0 \pm 0.1$ \\
\hline Control & $1 \cdot 6 \pm 0.1 *$ & $2 \cdot 4 \pm 0.1 *$ \\
\hline \multicolumn{3}{|c|}{ Serum (mg lipid/100 $\mathrm{ml}$ serum) } \\
\hline SF & $29 \pm 5$ & $44 \pm \mathrm{r} 2$ \\
\hline $\mathrm{SF}+$ linoleate & $82 \pm 2^{* * *}$ & $63 \pm 2 * *$ \\
\hline $\mathrm{SF}+$ linolenate & $80 \pm 5 * * *$ & $56 \pm$ I 5 \\
\hline $\mathrm{SF}+$ arachidonate & $42 \pm 6$ & $40 \pm 2$ \\
\hline Control & I $56 \pm 7 * * *$ & $87 \pm 4 * * *$ \\
\hline
\end{tabular}

Values significantly different from value for rats given the saturated-fat diet: ${ }^{*} P<0.05$; ** $P<0.01$; *** $P<0.001$.

De Pury \& Collins (1965), Bergström \& Carlson (1965) and Sinclair \& Collins ( 1968 ) have all shown that in deficient rats the concentration of free fatty acids in the serum is increased. In Table 6 it is shown that the administration of either linoleic acid or arachidonic acid reduced the concentration of free fatty acids, with the effect of arachidonate being most marked. 
Table 4. Expt 2. Liver and serum triglyceride fatty acid compositions (moles/100 moles fatty acid) from deficient rats given polyenoic fatty acids for $4 d$

(Mean values from four rats/group)

\begin{tabular}{|c|c|c|c|c|c|}
\hline Fatty acid & $\mathrm{SF}$ & $S F+18: 2$ & $S F+18: 3$ & $S F+20: 4$ & Control \\
\hline \multicolumn{6}{|c|}{ Liver } \\
\hline $14: 0$ & 0.9 & 0.9 & 0.8 & 0.9 & 0.9 \\
\hline $16: 0$ & $30 \cdot 1$ & $32 \cdot 7$ & $32 \cdot 5$ & $31 \cdot 7$ & $32 \cdot 3$ \\
\hline $16: 1$ & $12 \cdot 5$ & I I 6 & 10.7 & 8.5 & 10.8 \\
\hline $18: 0$ & $2 \cdot 2$ & $2 \cdot 8$ & 3.0 & $3 \cdot 6$ & $2 \cdot 6$ \\
\hline $18: 1$ & $53 \cdot 8$ & $5 I \cdot I$ & $52 \cdot 8$ & $54 \cdot 8$ & $45 \cdot 5$ \\
\hline I $8: 2 \omega 6$ & 0.5 & 0.9 & 0.2 & 0.5 & 7.9 \\
\hline \multicolumn{6}{|c|}{ Serum } \\
\hline $14: 0$ & $\mathrm{I} \cdot 6$ & 0.6 & 0.7 & 0.7 & 0.7 \\
\hline I 6:0 & $23 \cdot 4$ & $28 \cdot 3$ & $29^{\circ} \mathrm{I}$ & $28 \cdot x$ & $23 \cdot 5$ \\
\hline I 6:I & $9 \cdot 4$ & $8 \cdot 5$ & $6 \cdot 8$ & $4 * 4$ & 8.0 \\
\hline I 8:0 & $6 \cdot 5$ & $4 \cdot 8$ & $5 \cdot 7$ & $6 \cdot 0$ & 3.7 \\
\hline I $8: I$ & $5 I \cdot 3$ & $54 \cdot 3$ & $56 \cdot 2$ & $56 \cdot 0$ & $45 \cdot 6$ \\
\hline I $8: 2 \omega 6$ & $\mathrm{I} \cdot \mathrm{O}$ & $\mathrm{r} \cdot 9$ & 0.6 & 0.5 & $16 \cdot I$ \\
\hline $20: 3 \omega 9$ & $I \cdot 2$ & $1 \cdot 3$ & 0.9 & $\mathrm{I} \cdot 8$ & 0.0 \\
\hline $20: 4 \omega 6$ & 0.6 & 0.3 & 0.0 & $2 \cdot 5$ & $2 \cdot 4$ \\
\hline
\end{tabular}

$\mathrm{SF}$, saturated fat.

Table 5. Expt 2. Liver and serum phospholipid fatty acid compositions (moles/10o moles fatty acid) from deficient rats given polyenoic fatty acids for $4 \mathrm{~d}$

(Mean values from four rats/group)

\begin{tabular}{|c|c|c|c|c|c|}
\hline Fatty acid & SF & $\mathrm{SF}+\mathrm{I} 8: 2$ & $S F+18: 3$ & $\mathrm{SF}+20: 4$ & Control \\
\hline \multicolumn{6}{|c|}{ Liver } \\
\hline $16: 0$ & I 5.9 & $17 \cdot 2$ & $20 \cdot 1$ & 18.9 & $17 \cdot 1$ \\
\hline $16: I$ & $5 \cdot 6$ & $3 \cdot I$ & $3 \cdot 7$ & $2 \cdot 3$ & $2 \cdot 3$ \\
\hline I 8:0 & 24.0 & $27 \cdot 0$ & $29 \cdot 6$ & $29 \cdot 1$ & $27 \cdot 6$ \\
\hline I 8: I & $2 \mathrm{I} \cdot 5$ & 16.4 & $17 \cdot 2$ & 13.7 & 14.4 \\
\hline I $8: 2 \omega 6$ & $2 \cdot 2$ & $5 \cdot 8$ & $I \cdot I$ & 0.5 & $8 \cdot 4$ \\
\hline $20: 3^{\omega g}$ & I $5 \cdot 2$ & 5.7 & $6 \cdot 8$ & $I \cdot I$ & 0.0 \\
\hline $20: 4 \omega 6$ & $6 \cdot I$ & 12.5 & $3 \cdot 1$ & $25 \cdot x$ & 27.8 \\
\hline $20: 5^{\omega_{3}}$ & 0.2 & 0.7 & 6.0 & 0.3 & 0.2 \\
\hline $22: 5 \omega 6$ & $I \cdot 4$ & $5 \cdot 3$ & $2 \cdot 1$ & 4.6 & $1 \cdot 2$ \\
\hline $22: 5 \omega_{3}$ & 3.0 & $2 \cdot 8$ & $4 \cdot 1$ & $2 \cdot 9$ & 0.7 \\
\hline $22: 6 \omega_{3}$ & $4^{\circ} 9$ & $3 \cdot 5$ & $6 \cdot 2$ & I. 5 & 0.3 \\
\hline \multicolumn{6}{|c|}{ Serum } \\
\hline $16: 0$ & 24.0 & 20.7 & 23.0 & $24 \cdot 8$ & $22 \cdot 3$ \\
\hline $16: I$ & 3.4 & $2 \cdot 5$ & 30 & I. 5 & $\mathrm{I} \cdot 8$ \\
\hline $18: 0$ & $27 \cdot 2$ & 28.0 & $28 \cdot 9$ & 29.8 & 27.0 \\
\hline I $8: 1$ & 24.4 & $22 \cdot 0$ & 25.5 & $22 \cdot I$ & $15 \cdot 3$ \\
\hline $8: 2 \omega 6$ & $\begin{array}{r}2.4 \\
1.6\end{array}$ & 6.5 & 0.6 & 0.8 & $\begin{array}{l}13 \cdot 2 \\
11 \cdot 2\end{array}$ \\
\hline $20: 3 \omega 9$ & $16 \cdot 0$ & $7 \cdot 7$ & $8 \cdot 3$ & $2 \cdot 2$ & 0.0 \\
\hline $204 \omega 6$ & $3 \cdot 4$ & I 2.6 & 23 & 18.8 & $22 \cdot 4$ \\
\hline $205 \omega_{3}$ & 0.0 & 0.0 & 84 & 0.0 & c.o \\
\hline
\end{tabular}

$\mathrm{SF}$, saturated fat. 


\section{Interrelationships between serum lipids}

Examination of analyses of the serum lipids revealed a wide range of values both of concentrations of phospholipids and triglycerides and of their fatty acid compositions. Because of this scatter it has been possible to show that certain correlations were

Table 6. Expt 2. Serum free fatty acids from deficient rats given either linoleate or arachidonate for $4 d$

(Mean values with their standard errors; the numbers of determinations are shown in parentheses)

SF, saturated fat.

Serum free fatty acids

Diet $(\mu \mathrm{moles} / \mathrm{ml})$
(I) $\mathrm{SF}^{*}$
(2) $\mathrm{SF}$
$0.46 \pm 0.04(8)$
(3) SF+ linoleate
$0.4 \mathrm{I} \pm 0.03(4)$
(4) $\mathrm{SF}+$ arachidonate
$0.25 \pm 0.03(4)$
$0.09 \pm 0.03(4)$

* Sinclair \& Collins ( 1968).

Statistical comparisons: I v. $2-P>0.05 ; 2 v .3-P<0.05 ; 2 v .4-P<0.001 ; 3 v .4-P<0.05$.

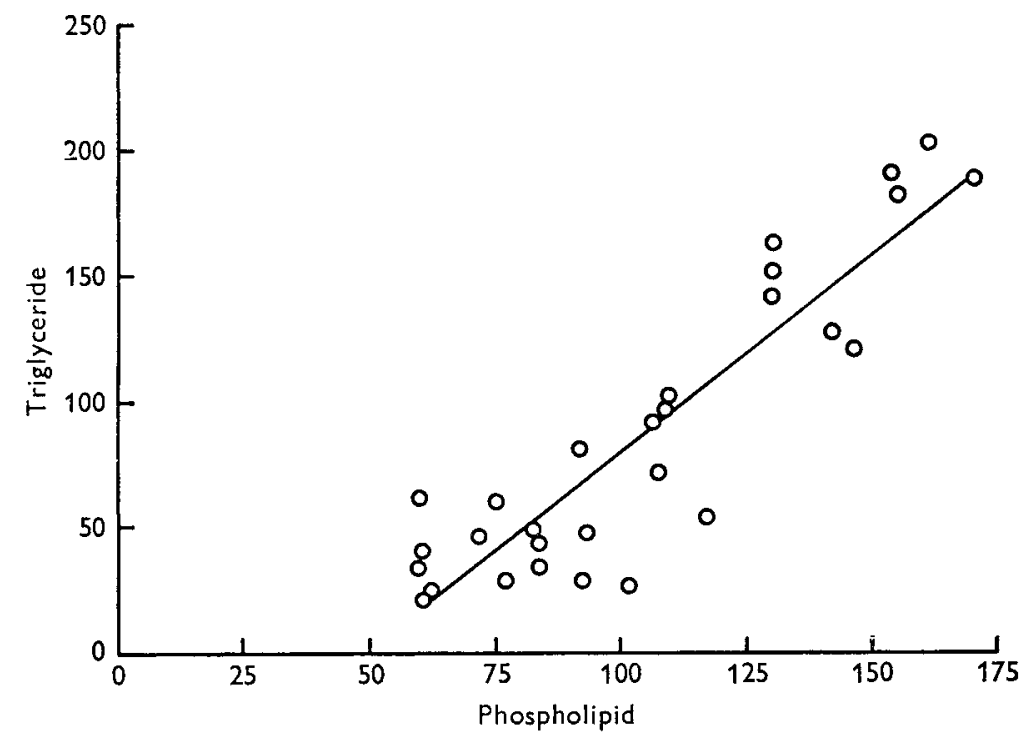

Fig. 3. Expt 3. Relationship in the rat between the concentration of phospholipids and triglycerides in the serum. The results are expressed as $\mu$ moles lipid/100 $\mathrm{ml}$ serum. The regression equation was $y=1 \cdot 57 x-76(P<0 \cdot 001)$.

significant. For example, Fig. 3 shows a plot of serum triglyceride concentrations against the corresponding figure for phospholipids. The regression equation was significant $(P<0.00 \mathrm{r})$. The amount of the fatty acids is necessarily correlated with the amount of phospholipids and hence it is necessary to use the percentage. Table 7 shows that the concentration of serum phospholipids was positively correlated to the percentage of linoleic and arachidonic acids, was negatively correlated to $5,8, \mathrm{II}$ eicosatrienoic, oleic and palmitoleic acids, and was not correlated with the remaining 
acids. When a similar analysis was performed on the amount of serum triglycerides and the percentage of triglyceride fatty acids it was found that linoleic acid gave a significant positive correlation. However, it is clear that since the polyenoic acid content of triglycerides is low, the fatty acid analyses were much less affected by the $4 \mathrm{~d}$ refeeding than the phospholipid fatty acids. Thus, also, though not shown in Fig. 3 or Table 7 , the concentration of serum triglycerides was significantly correlated with the fatty acid composition of the serum phospholipids.

Table 7. Expt 3. Relationships in the rat between the concentration of serum phospholipids and the percentage of the different fatty acids in the phospholipids

$\begin{array}{ccc}\text { Fatty acid } & \begin{array}{c}\text { Correlation } \\ \text { coefficient }\end{array} & P \\ \text { I6:0 } & -0.063 & >0.05 \\ \text { I6:1 } & -0.456 & <0.05 \\ 18: 0 & -0.090 & >0.05 \\ 18: 1 & -0.552 & <0.01 \\ \text { I8:2 } 266 & +0.644 & <0.001 \\ 20: 3 \omega 9 & -0.536 & <0.01 \\ 20: 4 \omega 6 & +0.595 & <0.001\end{array}$

Units: phospholipid concentrations in $\mu \mathrm{moles} / 100 \mathrm{ml}$ serum and individual fatty acid contents in moles/100 moles fatty acid.

Table 8. Expt 4. Comparisons of VLD lipoproteins from deficient rats given either linoleate or arachidonate for $4 d$

(The results from three separate experiments are shown)

\begin{tabular}{lcc}
\multicolumn{1}{c}{ Diet } & $\begin{array}{c}\text { Triglyceride } \\
\text { (mg/ro0 ml serum) }\end{array}$ & Phospholipid \\
SF & $31,57,32$ & $8 \cdot 5,8 \cdot 7,8 \cdot 6$ \\
SF+ linoleate & $68,57,27$ & $14,12,6 \cdot 1$ \\
SF+arachidonate & $5 \cdot 7,4 \cdot 5,12$ & $2 \cdot 1,3 \cdot 2,3 \cdot 5$ \\
Control & $110,168,142$ & $21,33,3 \circ$
\end{tabular}

VLD, lipoproteins of very low density.

$\mathrm{SF}$, saturated fat.

\section{VLD lipoproteins}

Table 8 shows the compositions of the VLD lipoproteins and it is clear that while linoleic acid caused a small increase in the triglycerides and phospholipids associated with this fraction, arachidonic acid caused a large fall. Table 9 shows the fatty acid compositions of the lipoprotein phospholipids, and the changes which occurred followed closely the pattern observed in the liver and serum phospholipids (Table 5).

\section{Low-temperature extraction of serum lipoproteins with heptane}

One possible conclusion from the results shown in Table 7 and Fig. 3 is that triglycerides are bound to phospholipids which in turn are bound to protein and that this binding is affected by the fatty acid composition of the phospholipids. In order to 
test the degree of binding of the phospholipids to the protein of the VLD lipoprotein, the frozen dried fraction was extracted with the heptane at $-18^{\circ}$ and the results are shown in Table I0. The phospholipid fatty acids in the fraction which was not extracted with the heptane (and hence potentially more firmly bound) showed a specific accumulation of stearic acid and of either arachidonic acid (normal rat) or 5,8, I Ieicosatrienoic acid (deficient rat). Phospholipids containing arachidonic acid would be expected to be more soluble in heptane than the more saturated phospholipids.

Table 9. Expt 4. Fatty acid composition (moles/roo moles fatty acid) of the VLD phospholipids from deficient rats given either linoleate or arachidonate for $4 d$

(Mean values from three rats on each diet)

\begin{tabular}{|c|c|c|c|c|}
\hline Fatty acid & $\mathrm{SF}$ & $S F+18: 2$ & $\mathrm{SF}+20: 4$ & Control \\
\hline I6:0 & 13.6 & $17 \cdot 2$ & $2 \mathrm{I} \cdot 8$ & 15.0 \\
\hline$I 6: I$ & 6.9 & $3 \cdot 3$ & $6 \cdot 2$ & $2 \cdot 0$ \\
\hline I $8: 0$ & $22 \cdot 4$ & $23 \cdot 2$ & 19.8 & $25 \%$ \\
\hline I $8: 1$ & $26 \cdot I$ & $20 \cdot 1$ & 18.6 & 134 \\
\hline I $8: 2 \omega 6$ & $3 \cdot 2$ & $6 \cdot 5$ & $2 \cdot 2$ & $10 \cdot 2$ \\
\hline $20: 3^{\omega 9}$ & 14.4 & $4 \cdot 8$ & I.O & 0.0 \\
\hline $20: 3 \omega 6$ & $3 \cdot 2$ & $2 \cdot 0$ & 0.6 & 0.8 \\
\hline $20: 4 \omega 6$ & 5.9 & $16 \cdot 8$ & $2 \mathrm{I} \cdot 2$ & 29.5 \\
\hline $20: 5 \omega_{3}$ & 0.6 & I.O & $2 \cdot 4$ & 0.5 \\
\hline $22: 5 \omega 6$ & $2 \cdot 5$ & $2 \cdot 1$ & $4 \cdot 8$ & 0.9 \\
\hline $22: 5 \omega_{3}$ & $1 \cdot 2$ & $3 \cdot 0$ & $1 \cdot 4$ & $2 \cdot 3$ \\
\hline
\end{tabular}

VLD, lipoproteins of very low density.

Table 10. Fatty acid composition (moles/100 moles fatty acid), in rats, of the phospholipid fractions, $(A)$ extractable and $(B)$ not extractable with heptane at $-18^{\circ}$, of the lipids from lipoproteins of VLD proteins

(Results are from three separate experiments)

\begin{tabular}{|c|c|c|c|c|c|c|}
\hline \multirow[b]{2}{*}{ Fatty acid } & \multicolumn{3}{|c|}{ A (extractable) } & \multicolumn{3}{|c|}{ B (not extractable) } \\
\hline & Control & Control & Deficient & Control & Control & Deficient \\
\hline $16: 0$ & $22 \cdot 8$ & 16.5 & $30 \cdot 2$ & $22 \cdot 8$ & I $9^{.} \mathrm{I}$ & I9.3 \\
\hline $16: 1$ & $2 \cdot 4$ & $\mathrm{I} \cdot 8$ & $8 \cdot I$ & $I \cdot 4$ & $x \cdot 7$ & $3: 3$ \\
\hline $18: 0$ & $18 \cdot 8$ & I9. I & I6. I & $29 \cdot 3$ & $25 \cdot I$ & 27.7 \\
\hline $18: 1$ & 15.8 & $15 \cdot 7$ & $28 \cdot 6$ & 10.8 & $I I \cdot I$ & 19.5 \\
\hline $18: 2 \omega 6$ & I $2 \cdot 8$ & $2 \mathrm{I} \cdot 4$ & $4 \cdot I$ & 14.0 & $19 \cdot 9$ & $2 \cdot 0$ \\
\hline $20: 3 \omega 9$ & 0.0 & 0.0 & $6 \cdot x$ & 0.0 & 0.0 & $20 \cdot 7$ \\
\hline $20: 3 \omega 6$ & $4 \cdot 4$ & $2 \cdot 0$ & $3 \cdot 0$ & 0.0 & 0.0 & $2 \cdot 0$ \\
\hline $20: 4 \omega 6$ & $\begin{array}{l}+4 \\
1 \mathrm{I} \cdot 8\end{array}$ & $\mathrm{I} 4 \cdot 9$ & $3 \cdot 8$ & $21 \cdot 7$ & $23 \cdot I$ & $2 \cdot 6$ \\
\hline $20: 5 \omega_{3}$ & II $\cdot 2$ & $8 \cdot 6$ & 0.0 & 0.0 & 0.0 & $2 \cdot 9$ \\
\hline
\end{tabular}

VLD, lipoproteins of very low density.

\section{DISCUSSION}

After feeding deficient rats with polyenoic fatty acids changes occur in the fatty acid compositions of the tissue lipids (Tables 4,5 and 9) and except for the serum triglycerides and VLD phospholipids, similar results have been reported previously by other workers (Mohrhauer \& Holman, 1963; Rahm, \& Holman, I964; Brenner \& Nervi, 1965; Caster, Mohrhauer \& Holman, I966; Catalá \& Brenner, ı967; Walker, 
1967). In the liver, serum and VLD phospholipids, feeding each polyenoic fatty acid for $4 \mathrm{~d}$ produced a characteristic pattern of fatty acids. Administration of the acids from the $\omega 6$ series increased these acids and decreased the acids from the $\omega_{3}$ series and vice versa. Also, supplementation with acids from both the above series caused a decrease in the acids from the $\omega 9$ series (oleic and $5,8, \mathrm{I}$-eicosatrienoic acid) with the $\omega 6$ acids being more effective in this decrease than the $\omega_{3}$ acid.

While large changes occurred in the phospholipid fatty acids, it is clear from Table 4 that after $4 \mathrm{~d}$ refeeding very little change occurred in the fatty acid composition of the liver and serum triglycerides. These findings are supported by the work of Brenner \& Nervi (1965) and Catalá \& Brenner (1967) and suggest that initially there is a preferential incorporation of linoleic, arachidonic and linolenic acids into phospholipids and it is only when the requirement for these in the phospholipids has been satisfied that linoleic acid is incorporated into triglycerides.

While changes in the fatty acid composition of tissue lipids have been observed previously, the effects of the essential fatty acids on the liver and serum lipid concentrations have not been investigated and it was of interest to study these.

Feeding an essential fatty acid to a deficient rat for $4 \mathrm{~d}$ did not cure the skin lesions but did increase the growth rate and the efficiency of utilization of the food. In deficient rats the concentration of free fatty acids in the serum is increased, the liver triglyceride concentration is raised and the serum triglyceride concentration is low.

Feeding linoleic and linolenic acids for $4 \mathrm{~d}$ did not affect the fatty liver although arachidonic acid did (Table 3). Sinclair \& Collins (r968) concluded that the likely cause of the fatty liver was the increased concentration of serum free fatty acids, and undoubtedly these are affected to a much greater extent by arachidonic acid than by linoleic acid (Table 6). This may be due to the effect of the prostaglandins on the hormone-sensitive lipase of the adipose tissue. These compounds appear to inactivate the lipase (Steinberg, Vaughan, Nestel \& Bergström, I963; Bergström \& Carlson, r 965 ) and are themselves formed from the essential fatty acids, so that a deficiency of the essential fatty acids could lead to a decreased concentration of prostaglandins and hence to an increased activation of the lipase, which in turn could lead to an increased serum free fatty acid concentration. Conceivably, arachidonic acid may be a more direct precursor of prostaglandins than the other fatty acids, thus explaining the greater effectiveness of arachidonic acid in reducing the amount of liver triglycerides.

The serum triglycerides were more affected by feeding with linoleic or linolenic acid than with arachidonic acid (Table 3 ). In both normal and deficient rats most of the serum triglycerides occur in the VLD and on feeding with linoleic acid the increase in VLD triglycerides paralleled the increase in serum triglycerides (Tables 3 and 8). However, when arachidonic acid was given the serum lipids were unaltered but the VLD concentration was decreased.

There have been many reports in the literature of differences between linoleic and arachidonic acids and these can be summarized as follows: (I) linoleic acid can be converted into arachidonic acid in animals but the reverse does not occur (Mead, Steinberg \& Howton, 1953; Steinberg, Slaton, Howton \& Mead, I 956; Mohrhauer \& Holman, 1963); (2) arachidonic acid is more effective than linoleic acid in 
curing some symptoms of the deficiency (Mohrhauer \& Holman, I963; Holman, 1964); (3) less arachidonic acid is oxidized to $\mathrm{CO}_{2}$ by rats than linoleic and other acids (Coots, $1964 a, b, 1965)$. Thus, the results for the rat-serum triglycerides confirm the difference between these two fatty acids and it is inferred that linoleic and arachidonic acids each have a specific role in the regulation of serum triglycerides. The essential fatty acids have also been shown to have a role in serum triglycerides in man (Collins, Sinclair, Royle, Coats, Maynard \& Leonard, i970).

Linoleic and arachidonic acids occur predominantly in the phospholipids and it has been shown that rat-liver phospholipids differ greatly in their relative turn-over (Collins, 1966 ). In rats, $\mathrm{r} h$ after injection of a radioisotope the phosphatidyl cholines and phosphatidyl ethanolamines containing linoleic, oleic and palmitoleic acids in the 2-position have a greater specific activity than those compounds containing arachidonic acid in the 2-position. In particular, I-stearoyl-2-arachidonoyl-sn-3-glycerylphosphorylcholine has a specific activity that is about one-tenth of any other molecular species (Arvidson, 1968; Trewhella \& Collins, 1969). It is felt that the simplest explanation for this slow turn-over is that the phospholipid is firmly bound to the lipoprotein membrane structure. The results of the extraction of the VLD lipoproteins with heptane at $-18^{\circ}$ appears to confirm this hypothesis and to suggest that this is also true of the I-stearoyl-2-(5,8, I I)-eicosatrienoyl-sn-3-glycerylphosphorylcholine. Thus, the difference in the function of linoleic and arachidonic acids may reflect this difference of binding and it may be concluded on the basis of the evidence presented in this paper that linoleic and arachidonic acids have different and specific roles in metabolism.

Financial support from the Australian Research Grants Committee is gratefully acknowledged. A. J. S. was a recipient of a Commonwealth Post Graduate Award.

\section{REFERENCES}

Alfin-Slater, R. B. \& Aftergood, L. (1 968). Physiol. Rev. 48, 758.

Arvidson, G. A. E. (1968). Eur. F. Biochem. 5, 415.

Bergström, S. \& Carlson, L. A. (1965). Acta physiol. scand. 64, 479.

Brenner, R. R. \& Nervi, A. M. (1965). F. Lipid Res. 6, 363.

Camejo, G. (1967). Biochemistry, Easton 6, 3228 .

Caster, W. O., Mohrhauer, H. \& Holman, R. T. (1966). F. Nutr. 89, 217.

Catalá, A. \& Brenner, R. R. (1967). Lipids 2, I I4.

Collins, F. D. (1966). Biochem. F. 99, I I7.

Collins, F. D., Sinclair, A. J., Royle, J. P., Coats, D. A., Maynard, A. T. \& Leonard, R. F. (I970). In Atherosclerosis. Proceedings of the Second International Symposium on Atherosclerosis [R. J. Jones, editor]. New York: Springer-Verlag.

Coots, R. H. (1964a). F. Lipid Res. 5, 468.

Coots, R. H. (1964b). F. Lipid Res. 5, 473 .

Coots, R. H. (1965). \%. Lipid Res. 6, 494.

De Pury, G. G. \& Collins, F. D. (1965). Biochim. biophys. Acta 106, 213.

Efromyson, M. A. (1960). In Mathematical Methods for Digital Computers p. г9г [A. Ralston and A.S. Wilf, editors]. New York and London: John Wiley \& Sons.

Galanos, D. S. \& Kapoulas, V. M. (1962). F. Lipid Res. 3, I34.

Gustafson, A. (1965). F. Lipid Res. 6, 512.

Havel, R. J., Eder, H. A. \& Bragdon, J. H. (1955). F. clin. Invest. 34, 1345.

Hofstetter, H. H., Sen, N. \& Holman, R. T. (1965). \%. Am. Oil Chem. Soc. 42, 537.

Holman, R. T. (x964). Fedn Proc. Fedn Am. Socs exp. Biol. 23, 1062.

Holman, R. T. (1968). Prog. Chem. Fats 9, 275. 
Horning, E. C., Ahrens, E. H. Jr, Lipsky, S. R., Mattson, F. H., Mead, J. F., Turner, D. A. \& Goldwater, W. H. (1964). F. Lipid Res. 5, 20.

Itaya, K. \& Ui, M. (1966). Clinica chim. Acta 14, 36r.

Leat, W. M. F. (1963). Biochem. 7. 89, 44 .

Lyman, R. L., Ostwald, R., Bouchard, P. \& Shannon, A. (I 966). Biochem. F. 98, 438.

Mead, J. F., Steinberg, G. \& Howton, D. R. (x953). F. biol. Chem. 205, 683.

Mohrhauer, H. \& Holman, R. T. (1963). F. Lipid Res. 4, I 5 I.

Rahm, J. J. \& Holman, R. T. (I 964). F. Nutr. 84, I 49.

Sinclair, A. J. \& Collins, F. D. (1968). Biochim. biophys. Acta 152, 498.

Snedecor, G. W. (1946). Statistical Methods 4th ed. Iowa: Iowa State College Press.

Steinberg, D., Vaughan, M., Nestel, P. J. \& Bergström, S. (1963). Biochem. Pharmac. 12, 764.

Steinberg, G., Slaton, W. H. Jr, Howton, D. R. \& Mead, J. F. (1956). F. biol. Chem. 220, 257.

Trewhella, M. A. \& Collins, F. D. (1969). Lipids 4, 304.

Walker, B. L. (1967). F. Nutr. 92, 23.

White, H. B. \& Quackenbush, F. W. (1962). F. Am. Oil Chem. Soc. 39, 5 I7. 